MSCRA

4,1

62

Received 15 November 2021 Revised 19 January 2022 Accepted 15 February 2022

\section{Big data analytics capability and supply chain performance: the mediating roles of supply chain resilience and innovation}

\author{
Mohammad Bahrami \\ Shahid Beheshti University, Tehran, Islamic Republic of Iran \\ Sajjad Shokouhyar \\ Department of Management and Accounting University of Shahid Beheshti, \\ Shahid Beheshti University, Tehran, Islamic Republic of Iran, and \\ Atiyeh Seifian \\ Shahid Beheshti University, Tehran, Islamic Republic of Iran
}

\begin{abstract}
Purpose - Big data analytics (BDA) capabilities can affect supply chain performance in several ways. The main purpose of this study was to understand how BDA capabilities could affect supply chain performance through supply chain resilience and supply chain innovation.

Design/methodology/approach - The study adopted a cross-sectional approach to collect survey-based responses to examine the hypotheses. Accordingly, 187 responses were collected and analyzed using partial least squares (PLS) in the SmartPLS3.

Findings - The results showed that BDA capabilities improve supply chain performance through resilience and innovation of the supply chain.

Originality/value - The present study also contributed to the existing literature by demonstrating the mediating role of supply chain resilience and supply chain innovation between BDA capabilities and supply chain performance. In this context, some theoretical and managerial implications were proposed and discussed.

Keywords Big data analytics capabilities, Dynamic capability view, Resilience, Innovation, Supply chain performance
\end{abstract}

Paper type Research paper

\section{Introduction}

Different organizations are under pressure in today's data-driven world to find innovative ways to create and deliver value to customers through supply chain management (SCM). The ability to extract big data for the purpose of gaining useful business insights is now the most important factor in gaining a competitive advantage in today's rapidly changing business environment. Specifically, developing a better understanding of how big data analytics (BDA) can add value to the organizational supply chain is of interest (Singh, N.P. and Singh, S., 2019). Supply chain (SC) executives are also turning to BDA for big data management, processing and analysis. In this context, BDA has traditionally been introduced as a primary motivator for organizational and supply chain performance (Jha et al., 2020). BDA enables organizations to improve the SC performance components of responsiveness, reliability and

(C) Mohammad Bahrami, Sajjad Shokouhyar and Atiyeh Seifian. Published in Modern Supply Chain Research and Applications. Published by Emerald Publishing Limited. This article is published under the Creative Commons Attribution (CC BY 4.0) licence. Anyone may reproduce, distribute, translate and create derivative works of this article (for both commercial and non-commercial purposes), subject to full attribution to the original publication and authors. The full terms of this licence may be seen at http:// creativecommons.org/licences/by/4.0/legalcode
Modern Supply Chain Research and Applications
Vol. 4 No. 1,2022 pp. $62-84$

Emerald Publishing Limited 2631-3871

DOI 10.1108/MSCRA-11-2021-0021 
customer service (Fernando et al., 2018). In this regard, Wamba et al. (2020) concluded that BDA could undoubtedly help improve SC performance. The concept of BDA capabilities extends the concept of big data to include all associated organizational resources (Mikalef et al., 2019), which may result in value creation and a competitive advantage for organizations. In terms of SCM, BDA capabilities allow businesses to investigate alternative options in the face of supply and demand uncertainty (Wang et al., 2016).

Dubey et al. (2021) also attempted to guide managers toward a deeper understanding of the complementary assets and competencies required to fully use the data analytics capability in order to improve supply chain resilience and acquire a competitive advantage in their study. The literature on the potential impact of BDA capabilities on performance appears to have grown in recent years. To extract meaningful theoretical and practical consequences, it is critical to understand whether the central artifacts of big data analytics capabilities result in competitive performance advantages and how these effects occur (Mikalef et al., 2020). According to several researchers, the impacts of BDA capabilities on performance are indirect since they are mediated by other organizational capabilities (Mikalef et al., 2020; Côrte-Real et al., 2017; Günther et al., 2017). Additionally, others say that investing in this sector does not always pay off, with only a few businesses benefiting from BDA capabilities (Gupta and George, 2016). Therefore more empirical research about how BDA capabilities contribute to SC performance is required (Gupta and George, 2016; Gunasekaran et al., 2017; Fernando et al., 2018; Choi et al., 2018; Mikalef et al., 2020). As a result, the research question posed here was:

$R Q$. How and through what mechanisms do BDA capabilities contribute to $\mathrm{SC}$ performance?

The dynamic capabilities view (DCV) was chosen as a robust theoretical foundation for addressing this research subject. In today's highly turbulent and unpredictable business climate, firm's resources and other organizational capabilities can only be maximized through dynamic capabilities (Teece et al., 1997). Additionally, BDA capabilities have been recognized as dynamic capabilities (Dubey et al., 2019; Singh, N.P. and Singh, S., 2019; Bahrami and Shokouhyar, 2021) that assist firms in navigating their route to success. Dynamic capabilities do not provide sustainable competitive advantages on their own; rather, they facilitate the creation of sustainable competitive advantages through the use of other organizational capabilities (Eisenhardt and Martin, 2000). Besides, BDA can be employed not only to forecast and prevent risks but also to shape innovative possessions, which can consequently deliver strategic benefits and sustainability to supply chains (Maheshwari et al., 2020). The most significant achievement of BDA is the generation of important insights regarding certain developments in the business and market environments (Wamba et al., 2017). Given the growing and unavoidable disruptions of supply chains (Kumar and Anbanandam, 2020), resilience (viz. the ability to withstand disruptions and to recover operational capability after disruptions occur) significantly contributes to the current philosophy of SCM (Sabahi and Parast, 2020). In this context, Dubey et al. (2021) noted that through SC resilience, BDA capabilities may provide organizations with a competitive advantage. On the other hand, innovation could be assumed as the most important tool for enterprises to keep their competitive advantages (Lin, 2008). Innovation also crucially contributes to responding to customers' changing demands and needs through product and service prompt changes (Kwak et al., 2018) along with improvements in organizational processes (Lee et al., 2011). Some scholars have further highlighted that BDA capabilities are the "next big things in innovation" and even frontiers for innovation capabilities (Gobble, 2013). SC innovation also improves the SCM's effectiveness regarding the capability of delivering on promises, meeting standards and dealing with problems (Kwak et al., 2018). In this regard, SCM requires BDA capabilities to demand forecasting and to compartmentalize
BDA capability
and supply
chain
performance

63 
MSCRA

4,1

64

market segmentation via SC innovation (Acar and Uzunlar, 2014; Fernando et al., 2018). To answer the research question, this study demonstrated the mediating role of $\mathrm{SC}$ resilience and $\mathrm{SC}$ innovation between BDA capabilities and SC performance.

Thus, the current study's objective is to ascertain how BDA capabilities affect SC performance via SC resilience and SC innovation. According to the $\mathrm{DCV}$, increased SC resilience and innovation were examined, and as a result, increased SC performance was viewed as an empirical indicator of potential advantage resulting from BDA capabilities. To address the research questions, a total number of 187 Iranian companies representing a range of industries were questioned. Accordingly, the results can insightfully guide managers on the ways of enhancement of SC performance.

\section{Theoretical background and development of hypotheses}

\subsection{BDA capabilities as dynamic capabilities}

Five 'Vs' distinguishes big data from traditional data. By 'Volume' it means the big data quantities that exponentially increase. 'Velocity' denotes the speed of collecting, processing and analyzing data in real-time. The term 'variety' refers to the range of data kinds collected in big data contexts. 'Veracity' refers to the data sources' reliability. 'Value' refers to the strategic, informational and transactional benefits associated with big data (Akter et al., 2016). Big data has become accessible to virtually all businesses (Jha et al., 2020), but it is difficult or even impossible to analyze and extract valuable insights from this type of data using conventional methods. Thus, while it is critical to understand the 'Vs' of big data, a critical question in contemporary research is how big data generates value (Gupta and George, 2016). Given the explosion in big data's importance in recent years, BDA has taken on a strategic role. BDA is a way to identify key opportunities and to discover and solve business problems. The BDA's critical insights can be invaluable in assisting firms in comprehending the changes occurring in the modern work world. To obtain these essential insights and ensure the success of big data projects, considerations beyond data, tools and analytical approaches must be made. As a result, the notion of BDA capabilities was introduced in order to broaden the scope of big data to encompass all organizational resources (Mikalef et al., 2020). By mobilizing and reorganizing organizational resources, BDA capabilities enable the organization to process, analyze and visualize data, ultimately providing useful insights to enhance decision-making, planning and execution of the organization's missions (Srinivasan and Swink, 2018; Dubey et al., 2019; Mikalef et al., 2020). According to this view of BDA capabilities, they can be viewed as a dynamic capability for the organization, as dynamic capabilities entail finding and shaping opportunities, investing in existing opportunities and sustaining a competitive advantage through promotion and mobilization and reorganize organizational resources (Teece, 2007). It is critical to recognize that, while dynamic capabilities are a necessary condition for obtaining a competitive advantage in today's dynamic and unpredictable circumstances, they are insufficient; success requires additional resources and capabilities developed by dynamic capabilities (Teece et al., 1997; Eisenhardt and Martin, 2000). Thus, insights gained through BDA capabilities alter strategic orientations, business processes and the organizational communication network, thereby assisting other organizational capabilities in strengthening these intermediate capabilities and thereby increasing the organization's value creation (Mikalef et al., 2018; Warner and Wäger, 2019).

\subsection{SC resilience}

Today's unpredictable situations and settings have exacerbated the issue of supply chain interruption (Christopher and Peck, 2004; Ambulkar et al., 2015). Disruption is defined as any 
internal or external threat that disrupts the supply chain's flow of products and services (Jüttner and Maklan, 2011; Craighead et al., 2007). Given the increasing severity and frequency of supply chain interruptions, the issue of resilience has taken on a new prominence in SCM as a critical need (Craighead et al., 2007; Pettit et al., 2013; Sabahi and Parast, 2020). Holling (1973), a pioneer in the field of resilience research, defines resilience as a system's ability to absorb change. According to Brandon-Jones et al. (2014) supply chain resilience refers to the supply chain's ability to resume normal operations in a fair amount of time following a disturbance. SC resilience has three main phases as follows: a) anticipation (proactive thinking and planning); b) resistance (maintaining structure and function); c) recovery and response (quick and efficient reactions) (Kamalahmadi and Parast, 2016).

\subsection{SC innovation}

Supply chain innovation consists of processes and procedures that are improved through technology in the outbound supply chain and changes to products, processes or services that either promote effectiveness or increase ultimate customer satisfaction (Seo et al., 2014). Wong and Ngai (2019) showed that research on SC innovation has mainly used the resourcebased view (RBV), because SC innovation is a valuable, inimitable, rare and non-substitutable resource. Therefore, companies that realize SC innovation are usually superior to their competitors. Based on previous studies (Flint et al., 2008; Hazen et al., 2012; Lee et al., 2014; Kwak et al., 2018), the dimensions of SC innovation can be interpreted as process innovation and technology innovation. The aim of technological innovation is strengthening real-time tracking technologies, innovative logistics equipment and integrated information systems throughout the supply chain, which is a key factor in differentiating logistics services (Lin, 2008) and ultimately creating value for end customers (Christopher, 2005). Process innovation refers to re-engineering and re-designing the supply chain with the ultimate goal of improving service quality and reducing costs (Kwak et al., 2018). There are two reasons for the importance of process innovation: first, it results in product innovation (the ability to develop new products and services to meet customer expectations), and second, process innovation is directly related to the level of output produced (Mikalef and Krogstie, 2018).

\subsection{SC performance}

In the literature, there are two distinct groups of general rationales for the study of SC performance (Sezen, 2008). The first group is concerned with how SC performance is measured. In an influential study, Beamon (1999) used resources (including inventory, cost of using different resources and return on investment), output (including customer satisfaction, sales volume and profit) and flexibility (including new product flexibility, supply flexibility, mix flexibility and volume flexibility) to measure SC performance. Since then, many researchers have used this framework as the basis for their work on measuring $\mathrm{SC}$ performance (Chang et al., 2019). Accordingly, SC performance management is central to organizations gaining and maintaining competitive advantage (Ramezankhani et al., 2018). The second group seeks to find ways to improve SC performance (Sezen, 2008). An organization's success depends primarily on its supply chain's performance (Rosenzweig et al., 2003). The present study attempts to investigate how BDA capabilities improve SC performance. For this study's purpose, special focus has been given to end-customer satisfaction in terms of quality and cost (Dwayne Whitten et al., 2012).

\subsection{BDA capabilities and SC performance}

The big data revolution is in full swing and has had a major impact on SCM. The advent of big data allows for the consideration of complicated factors in designing a supply chain, thus enabling the advancement of a powerful supply chain network (Wang et al., 2018a). Waller and Fawcett (2013) urged scholars to explore the application of Big Data in the supply chain
BDA capability
and supply
chain
performance

65 
MSCRA

4,1

66

and emphasized the importance of BDA technology in SCM. Based on their discussion, Big Data is employed in SCM to enhance competencies and provide novel capabilities. Li et al. (2018) showed that demand chain management has a significantly better performance when paired with e-commerce and big data benefits compared to traditional SCM practices. Wang et al. (2018b) conducted an assessment of supply chain analytics' contribution to logistics and SCM by applying big data strategies. Mishra et al. (2018) believe that to improve the SCM efficiency of e-commerce, big data can be used as a robust tool. The information gained through Big Data is capable of maximizing productivity, collaboration, as well as speed, along with visibility while improving interactions with supply chain actors. Integrating BDA into operations and supply chains helps companies better realize their customers, minimize service costs, manage risks efficiently and generate new and unforeseen revenue streams (Mishra et al., 2018). Because of its significant operational and strategic potentials, BDA can be considered a game-changer that increases corporate efficiency and success (Wamba et al., 2017; Maheshwari et al., 2020). Jha et al. (2020) explain that big data and BDA are typically viewed as core drivers of supply chain and organizational performance. Kache and Seuring (2017) showed that BDA capabilities could contribute to supply chain visibility and transparency, a better understanding of customer behavior and operational efficiency. Wamba et al. (2020) concluded that BDA could certainly help improve supply chain function and performance. BDA capabilities enhance supply chain efficiency by increasing operational efficiency, reducing costs and increasing profitability (Fernando et al., 2018; Côrte-Real et al., 2020). Given the above, despite the high potential of BDA capabilities to improve firm-level and SC performance and researchers' considerable attention to this issue, it appears that their impact is not well understood and the extent to which BDA capabilities affects SC performance is still unknown, and more empirical evidence is needed in this regard, according to the researchers (Dubey et al., 2021; Mikalef et al., 2020). Since this study is concerned with the generative mechanism by which BDA capabilities improve SC performance, the first hypothesis is considered for test the direct relationship between $\mathrm{BDA}$ capabilities and $\mathrm{SC}$ performance.

\section{H1. BDA capabilities have a direct positive effect on $\mathrm{SC}$ performance.}

\subsection{BDA capabilities, SC resilience and SC performance}

The concept of resilience is an unavoidable necessity in the supply chain to survive in a highly competitive environment. It also plays an inevitable role in SC performance (Ramezankhani et al., 2018). Achieving SC resilience requires long-term strategic investment (Papadopoulos et al., 2017). According to Dubey et al. (2019), visibility and analytical capabilities complement and support one another. To summarize, investing in the development of organizational analytical capabilities results in an improvement in visibility, which results in increased supply chain resilience (Brandon-Jones et al., 2014; Sabahi and Parast, 2020). Using BDA technology, a novel feature of proactive planning is enabled for risk management infrastructure and enhances the ability for resource reconfiguration in the recovery phase (Ivanov et al., 2019). BDA capabilities help identify and manage supply chain risks through its tangible resources (Singh, N.P. and Singh, S., 2019). Human capabilities (from BDA capabilities) can also improve the ability to respond to disruptions (Mandal, 2018). Additionally, evidence from previous research supports the hypothesis of a positive relationship between BDA capabilities and SC resilience. Dubey et al. (2021) explained how the ability to analyze data improves SC resilience through moderating effects of organizational flexibility. Moreover, Papadopoulos et al. (2017) developed a theoretical framework for supply chain network resilience using BDA. According to Mandal (2018), the key factors enabling supply chain agility include BDA business knowledge, BDA technology management knowledge and BDA relationship knowledge. 
Singh, N.P. and Singh, S. (2019) showed that with the adoption of BDA capabilities by organizations, they would be enabled to efficiently leverage resident knowledge and improve SC resilience capability. Mandal (2019) pointed out the BDA management capabilities as important enabling factors of supply chain preparedness, supply chain alertness and supply chain agility. However, he believes that the important role of BDA in the development of SC resilience is not clearly understood. Therefore, we propose:

H2. BDA capabilities positively impact $\mathrm{SC}$ resilience.

Supply chain disruptions have a serious impact on any supply chain as they disrupt the flow of information, materials and money and prevent the regular activities of supply chains, resulting in nothing but reduced efficiency and competitiveness (Ramezankhani et al., 2018). In such situations, quick and effective supply chain response to disruptions is critical (Ponomarov and Holcomb, 2009). The negative impact of supply chain disruptions can be prevented through resilience, while it also helps in recovering to a favorable level of performance in a desirable time after the impact of an incident (Wieland and Wallenburg, 2013).

In today's volatile climate, SC resilience is a must (Gölgeci and Kuivalainen, 2020). A number of previous research have found a favorable association between resilience and various dimensions of performance (Hohenstein et al., 2015; Ramezankhani et al., 2018; Liu and Lee, 2018; Gölgeci and Kuivalainen, 2020). Chowdhury and Quaddus (2017) showed that the SC resilience scale potentially predicts supply chain operational vulnerability and SC performance better. Altay et al. (2018) believed that SC resilience is a dynamic capability that significantly impacts SC performance. The result of SC resilience is that even in disruptions, business processes are implemented in the shortest possible time, and services are provided that ultimately meet customer needs (Liu and Lee, 2018). Not only is the customer satisfied (Govindan et al., 2015), but profitability does not stand still; this means better customer service and higher financial performance (Wieland and Wallenburg, 2013). Therefore, we propose:

\section{H3. $\mathrm{SC}$ resilience positively impacts $\mathrm{SC}$ performance.}

Recent research indicates that IT in general (DeGroote and Marx, 2013) and BDA capabilities in particular, such as technological advancements, improve company performance through enhancing supply chain agility (Dubey et al., 2019). In this context, Dubey et al. (2021) stated that data analytics capabilities enable firms to gain competitive advantage through SC resilience. Bahrami and Shokouhyar (2021) demonstrated that BDA capabilities boost the firm's performance by enhancing SC resilience. Business analytics capabilities assist management in making decisions and improve supply chain visibility and innovation, hence enhancing business performance and reducing environmental variability (Singh, N.P. and Singh, S., 2019). BDA capabilities have a vital role in mitigation of disaster and enables organizations to react to disruptive events (Redman, 2014). BDA enables enterprises to strengthen their resilience skills for risk management in the supply chain (Singh, N.P. and Singh, S., 2019). Therefore, we propose:

H4. SC resilience mediates the link between BDA capabilities and SC performance.

\subsection{BDA capabilities, SC innovation and SC performance}

BDA capabilities that are able to extract environmental information to identify and exploit new business opportunities can consistently lead to innovation in organizations (Bose, 2009; Chae, 2014; Wang and Dass, 2017; Rialti et al., 2018). Functions enabled by strong BDA capabilities can facilitate the ability to change technology (Mikalef et al., 2020). The importance of BDA resources varies depending on contextual factors, and specific combinations lead to high capabilities in incremental and radical process innovation
BDA capability and supply chain

performance 
MSCRA

4,1

\section{8}

(Mikalef and Krogstie, 2018). BDA capabilities enable organizations to gain insights that help them strengthen their dynamic capabilities, with successive positive effects on incremental and radical innovation capabilities (Mikalef et al., 2019). Lozada et al. (2019) analyzed the present relationship between BDA capabilities and co-innovation and showed that BDA capabilities directly and positively affect co-innovation. Moreover, BDA has a positive and significant impact on the innovation capabilities of the service supply chain (Fernando et al., 2018). Despite the growing interest in understanding the big data phenomenon and its impact on various business contexts, little experimental research has analyzed BDA potentials in relation to innovation (Mikalef and Krogstie, 2018; Lozada et al., 2019). We therefore propose:

H5. BDA capabilities positively impact SC innovation.

Innovation plays a critical role in responding to the changing demands and needs of customers through timely product and service modifications (Kwak et al., 2018) and organizational process improvement (Lee et al., 2011). Although scattered in the literature due to the multifaceted nature of innovation, previous studies support a positive relationship between SC innovation and various dimensions of SC performance (Lin, 2008; Seo et al., 2014; Lee et al., 2014; Panayides and Lun, 2009; Fernando et al., 2018). Research indicates that the focus of $\mathrm{SC}$ innovation is on operational issues and processes, which cover networking, management practices, procurement and distribution (Chapman et al, 2002). The result can be a competitive advantage and sustainable development in services (Isaksson et al., 2010). According to Lii and Kuo (2016), an innovation-based supply chain has positive effects on SC performance. Al-Sa'di et al. (2017) investigated business processes and indicated that process innovation results in sustainable organizational competitive advantage. Product innovation leads to more productive work, higher annual sales and better organizational performance (Wadho and Chaudhry, 2018). In general, SC innovation can be said to improve supply chain effectiveness in terms of delivering on promises, meeting standards and solving problems (Kwak et al., 2018). Therefore, we propose:

\section{H6. SC innovation positively impacts $\mathrm{SC}$ performance.}

Previous studies have widely noted the importance of innovation as one of the remarkable strategic advantages achieved through the use of information systems (Wang et al., 2018b). BDA helps organizations change to gain a competitive advantage (Mikalef and Krogstie, 2018). BDA capabilities can bring about fundamental changes in processes through process reconfiguration and adjustment of operational inefficiencies (Wang et al., 2016); it can also significantly impact technological capabilities. Nowadays, the use of innovative technologies has not only improved operational efficiency and increased mutual benefits as a facilitator of logistics and marketing activities (Bello et al, 2004), but also helps to improve inventory management effectively (Christopher, 2005). BDA capabilities improve the visibility of organizations to understand better the internal and external environment (Chung and Tseng, 2012); so that they could affect the innovation capabilities of supply chain members. Business analytics in enterprise processes provides critical information to organizations and enables them to play a more innovative role in the supply chain (Laursen and Thorlund, 2016). Therefore, we propose:

H7. SC innovation mediates the link between $\mathrm{BDA}$ capabilities and $\mathrm{SC}$ performance.

\section{Research design}

\subsection{Sample and data collection}

Notwithstanding that most research on information technology (IT) has been thus far carried out in developed countries, some studies have successfully included Iranian data into their 
overall findings (Ashrafi et al., 2019). The results from a study in the supply chain context of Iranian automotive manufacturers had confirmed that conceptualizing supply-chain business intelligence competencies could be an important enabler for supply chain agility regarding agile capabilities as well as performance (Sangari and Razmi, 2015). In the context of SCM in developing countries, Queiroz and Telles (2018) had further analyzed the BDA conditions at various levels of SCM in several companies in Brazil. Concerning the impact of big data on supply chain management, they stated that finding critical success elements in other growing economies could be beneficial. Motivated by the above-noted evidence and with the assistance of the database received from the Ministry of Industry, a total number of 367 companies were selected. Different industries were selected to obtain the highest insights on the development of BDA capabilities in different contexts (see Figure 1).

The survey approach was used to evaluate the research hypotheses because it enables the correct documenting of norms, identification of extreme information and the delineation of correlations between various variables in a sample (Gable, 1994). Moreover, it facilitated conceptual models' examination according to real-world data (Flynn et al., 1990). Before the principal survey, the reliability and validity of the measures were tested by using a pilot study. For this purpose, all survey questions were precisely translated into Persian. Then, indepth interviews were conducted with ten senior managers working in SCM, and the opinions of four assistant professors were obtained to ensure content validity and translation accuracy. With reference to the given pre-test, good reliability and validity for the measures were concluded. The inquiry began with definitions and examples of big data, BDA and BDA capabilities, to help respondents comprehend big data in SCM and get more accurate replies. Because survey-based research is always prone to bias, Armstrong and Overton's (1977) recommendations for evaluating non-response bias were followed. The $t$-test found no significant difference between early and late respondents in this investigation. In the instance of this study, the survey was developed with a single respondent in mind. The targeted respondents were senior managers holding relevant academic degrees and having practical backgrounds in business analytics. They were typically holding positions such as supply chain manager, marketing and purchasing director, as they possessed fundamental experiences regarding SCM, as well as operations managers who were knowledgeable about information systems, risk management programs and effects of innovation on supply chain processes. Moreover, IT managers were recruited since they had more BDA knowledge regarding supply chain processes and performance outcomes (Queiroz and Telles, 2018).

Taking into consideration the aforementioned cases and contacting the human resources management in each company, the suitable respondents were identified and the necessary data was collected within three weeks via an email questionnaire. One week after the first

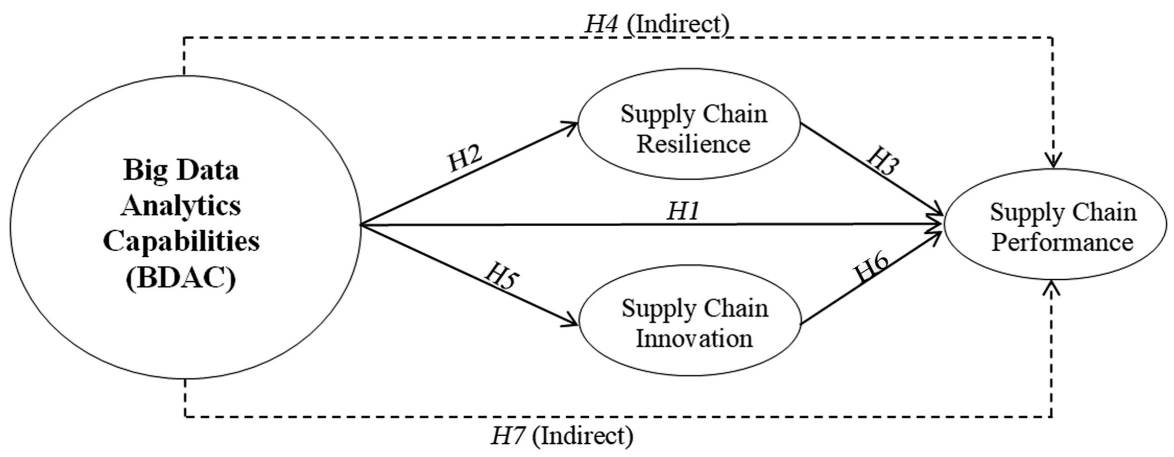

BDA capability and supply chain

performance

69
Figure 1. Research model 
MSCRA

4,1

round, reminder emails were sent, and the second round was sent in the third week. Finally, a total of 202 questionnaires were collected. After eliminating a number of partial received responses, a total of 187 useable responses were recovered, indicating a response rate of $38.96 \%$ (see Table 1 ).

\subsection{Measurement items}

The survey instrument scales were taken from prior scientific research to make sure that they had the required face and content validity. The entire survey contained 31 items. BDA capabilities were measured on the 10-item scale adapted from Côrte-Real et al. (2020). SC performance was also measured via an 11-item scale adapted from Gunasekaran et al. (2017). Of note, such items had been developed by Dwayne Whitten et al. (2012) to examine SC performance in a comprehensive study. The SC resilience was also assessed based on 4 -items developed by Dubey et al. (2021), who examined the effect of BDA capabilities on SC resilience and competitive advantage in firms. The items were originally developed by Brandon-Jones et al. (2014) following an analysis of the speed with which businesses respond to disruptions and recover from them. For supply chain innovation, The Kwak et al., 2018 scales (6 items) were applied, which were used in a study on the relationship between risk management capabilities, supply chain innovation and competitive advantage in global supply chains. All constructs were considered reflectively. The whole scales were provided in a 7-point Likerttype format (from strongly disagree to agree strongly) (see Table A1).

\section{Data analysis and results}

We used Smart PLS 3.0 in order to test the research models. This software uses partial least squares structural equation modeling (PLS-SEM). PLS may analyze complex models with

Respondents $(N=187)$

Frequency $(\%)$

Job title type

Supply chain manager $\quad 45.5$

Marketing manager $\quad 14.2$

$\begin{array}{lr}\text { Operations manager } & 7.1\end{array}$

$\begin{array}{ll}\text { IT manager } & 33.2\end{array}$

Industry type

Oil \& Gas

11.4

Automotive $\quad 13.2$

Textiles $\quad 4.1$

$\begin{array}{lr}\text { Pharmaceuticals } & 5.9\end{array}$

$\begin{array}{lr}\text { Manufacturing } & 13.4\end{array}$

Electrical equipment $\quad 8.2$

$\begin{array}{lr}\text { Transport services } & 10.6\end{array}$

$\begin{array}{ll}\text { ICT } & 11.1\end{array}$

$\begin{array}{lr}\text { Electrical equipment } & 8.9\end{array}$

\begin{tabular}{ll} 
Construction & 7.4 \\
\hline
\end{tabular}

$\begin{array}{ll}\text { Other } & 5.8\end{array}$

$\begin{array}{ll}\text { Number of employees } & \\ 0-50 & 22.0\end{array}$

$\begin{array}{ll}51-100 & 17.1 \\ 101-500 & 12.0\end{array}$

$\begin{array}{llr}\text { Table 1. } & 101-500 & 16.4\end{array}$

Respondent $\quad 501-1,000 \quad 19.3$

$\begin{array}{lll}\text { characteristics } & 1,001-10,000 & 25.2\end{array}$ 
fewer sample sizes and assess exogenous variables' predictive potential (Peng and Lai, 2012; Dijkstra and Henseler, 2015). Variance-based PLS-SEM can manage both measurement and structural models (Hair et al., 2013). According to Hair et al. (2011) proposed model, an adequate sample size is "ten times the largest number of formative indicators used for measuring one construct" and "ten times the largest number of structural paths directed at a specific latent construct in the structural model." Thus, 187 replies appear to be a sufficient sample size based on the proposed model.

\subsection{Measurement model}

The measurement model quality was also assessed using the analysis of reliability and validity. The construct and item levels of reliability were assessed, with composite reliability (CR) and Cronbach's alpha (CA) values calculated at the construct level. To maintain construct internal consistency, CA and CR indices have to be between 0.7 and 0.9 (Hair et al., 2016). Such values were above 0.7 in this study. So the measuring model showed strong internal consistency. Except for SCP5 and SCI3, all measurement item loadings surpassed 0.7, proving the indicators' reliability. The SCP5 and SCI3 were not excluded because the obtained CR and convergent validity were above their minimum value (Hair et al., 2016) (see Table 2).

Validity was then determined using convergent and discriminant validity tests (Hair et al., 2014). For convergent validity, all values for average variance extracted (AVE) were over the threshold of 0.5 , meaning each construct explained more than $50 \%$ of the variation of its indicators (Hair et al., 2016). Discriminant validity refers to the ability to measure several constructs independently. Three tests were done on discriminant validity. To begin, each construct's AVE square root was checked against its highest association with other constructs (Fornell and Larcker, 1981). Then, in the manner described by Farrell (2010), each indicator's outer loading was examined to determine if it was greater than its cross-loadings with other constructs. Finally, the heterotrait-monotrait (HTMT) ratio of the correlations was calculated according to Henseler et al. (2015). The HTMT has to be less than one (preferably $<0.85$ ) to clearly distinguish two components (Henseler et al., 2016). The values obtained in this study (less than 0.85) accordingly indicated enough discriminant validity and the results generally confirmed it (see Tables 2 and 3).

\subsection{Common method bias (CMB)}

The relationship between independent and dependent variables can be influenced by CMB due to relying on only one respondent (Podsakoff and Organ, 1986). CMB can be derived from societal desirability or the consistency concept (Podsakoff et al., 2003). Therefore, our model incorporates a number of methods for reducing the likelihood of negative outcomes. The Harman one-factor test was used to respond to Podsakoff and Organ (1986). The complete variance was explained by the first extracted factor, which accounted for around $27.37 \%$ $(<50 \%)$ of the variance, demonstrating that $\mathrm{CMB}$ is not a concern. Our model was found to be free of CMB after performing a complete collinearity test, which revealed a value of less than 3.3 for each VIF (Kock, 2015). CMB, based on these findings, does not appear to be a substantial concern.

\subsection{Structural model}

Following Hair et al. (2019), after the collinearity test established that there was no collinearity in our study, we used the $R^{2}$ value to estimate the effect of exogenous constructs. The variance is measured by the $R^{2}$ that is described in each of the endogenous constructs. So it measures the model's explanatory power (Hair et al., 2019). Significant, moderate or weak
BDA capability
and supply
chain
performance 


\begin{tabular}{|c|c|c|c|c|c|c|c|c|}
\hline \multirow{6}{*}{$\begin{array}{l}\text { MSCRA } \\
4,1\end{array}$} & Constructs & ID & Factor loading & Mean & $\mathrm{SD}$ & $\mathrm{CA}$ & $\mathrm{CR}$ & AVE \\
\hline & BDA capabilities & BDAC1 & $0.78^{* * * *}$ & 5.10 & 1.07 & 0.736 & 0.845 & 0.647 \\
\hline & & BDAC2 & $0.81^{* * * *}$ & & & & & \\
\hline & & BDAC3 & $0.73^{* * *}$ & & & & & \\
\hline & & BDAC4 & $0.79 * * *$ & & & & & \\
\hline & & BDAC5 & $0.84^{* * * *}$ & & & & & \\
\hline \multirow{24}{*}{72} & & BDAC6 & $0.81^{* * *}$ & & & & & \\
\hline & & BDAC7 & $0.89 * * *$ & & & & & \\
\hline & & BDAC8 & $0.86^{* * * *}$ & & & & & \\
\hline & & BDAC9 & $0.79 * * *$ & & & & & \\
\hline & & BDAC10 & $0.94 * * *$ & & & & & \\
\hline & SC resilience & SCR1 & $0.73^{* * * *}$ & 4.15 & 0.94 & 0.858 & 0.778 & 0.603 \\
\hline & & SCR2 & $0.78^{* * * *}$ & & & & & \\
\hline & & SCR3 & $0.80^{* * * *}$ & & & & & \\
\hline & & SCR4 & $0.77^{* * * *}$ & & & & & \\
\hline & SC innovation & SCI1 & $0.73 * * *$ & 3.66 & 0.73 & 0.836 & 0.880 & 0.552 \\
\hline & & $\mathrm{SCI} 2$ & $0.79 * * *$ & & & & & \\
\hline & & SCI3 & $0.62^{* * *}$ & & & & & \\
\hline & & SCI4 & $0.71^{* * * *}$ & & & & & \\
\hline & & SCI5 & $0.82^{* * * *}$ & & & & & \\
\hline & & SCI6 & $0.76^{* * * *}$ & & & & & \\
\hline & $\mathrm{SC}$ performance & SCP1 & $0.75^{* * * *}$ & 4.86 & 1.01 & 0.887 & 0.913 & 0.601 \\
\hline & & SCP2 & $0.83^{* * *}$ & & & & & \\
\hline & & SCP3 & $0.77 * * *$ & & & & & \\
\hline & & SCP4 & $0.76^{* * * *}$ & & & & & \\
\hline & & SCP5 & $0.66^{* * *}$ & & & & & \\
\hline & & SCP6 & $0.71 * * *$ & & & & & \\
\hline & & $\mathrm{SCP} 7$ & $0.82^{* * * *}$ & & & & & \\
\hline & & SCP8 & $0.75^{* * * *}$ & & & & & \\
\hline & & SCP9 & $0.79 * * *$ & & & & & \\
\hline & & SCP10 & $0.81^{* * *}$ & & & & & \\
\hline ptive and & & SCP11 & $0.74 * * *$ & & & & & \\
\hline
\end{tabular}

psychometric table of $\quad$ Note(s): $\mathrm{BDA}=$ Big Data Analytics; $\mathrm{SC}=$ Supply Chain; $\mathrm{SD}=$ Standard Deviation; $\mathrm{CA}=$ Cronbach Alpha; measurements

$\mathrm{CR}=$ Composite Reliability; AVE $=$ Average Variance Extracted; $* * * p<0.001$

\begin{tabular}{llcccc}
\hline & & $(1)$ & $(2)$ & $(3)$ & $(4)$ \\
\hline$(1)$ & BDA capabilities & 0.87 & & & \\
$(2)$ & SC resilience & 0.59 & 0.83 & & \\
$(3)$ & SC innovation & 0.43 & 0.38 & 0.79 & \\
$(4)$ & SC performance & 0.58 & 0.33 & 0.46 & 0.81 \\
\hline
\end{tabular}

endogenous latent variable $R^{2}$ values are $0.75,0.50$ or 0.25 (Henseler et al., 2012; Hair et al., 2011). Table 4 shows appropriate $R^{2}$ values for all dependent variables in the structural model. The $R^{2}$ score for the SC performance was 0.51 , demonstrating good support for the research model. Following that, the Stone-Geisser $Q^{2}$ value estimate procedure is used to determine the predictive relevance of the inner model (Hair et al., 2016). As shown in Table 4, $Q^{2}$ for all dependent variables is greater than zero, indicating appropriate predictive relevance (Hair et al., 2016). Then, the Cohen (1988) $f^{2}$ formula was used to determine the $f^{2}$ value of the BDA capabilities, which was found to be more than the cut-off value of 0.0 . To assess model fitness, we evaluated The Goodness-of-Fit (GoF by using PLS-SEM 
(Henseler et al., 2016). The model's overall GoF was 0.50, as determined using the following equation (Alolah et al., 2014): $\mathrm{GoF}=\sqrt{\mathrm{A} \overline{\mathrm{V}} \mathrm{E} \times \overline{\mathrm{R}} 2}$. Table 4 also gives the overall model fit $(\mathrm{GoF})$ values for each dependent variable.

\subsection{Hypotheses testing}

We used bootstrapping with 5,000 samples to determine the relevance of path coefficients. Based on the obtained statistical results, except for the $\mathrm{H} 1$ (BDA capabilities $\rightarrow \mathrm{SC}$ performance) hypothesis, $\mathrm{H} 2$ (BDA capabilities $\rightarrow \mathrm{SC}$ resilience), $\mathrm{H} 3$ (SC resilience $\rightarrow \mathrm{SC}$ performance), $\mathrm{H} 5$ (BDA capabilities $\rightarrow \mathrm{SC}$ innovation) and $\mathrm{H} 6$ (SC innovation $\rightarrow \mathrm{SC}$ performance) hypotheses were supported. Path coefficients were showed in Figure 2.

\subsection{Mediation test}

We utilized the PLS-SEM mediation test to assess the magnitude of mediating effects of supply chain resilience and supply chain innovation on the connection between BDAC and supply chain performance (Hair et al., 2016; Preacher and Hayes, 2008). This study used PLSSEM for the mediation test, which has more statistical power than earlier testing methodologies, such as the parametric Sobel (1982) test (Matthews et al., 2018). We began by assessing the relevance of indirect impacts, followed by the direct influence of BDA capabilities on SC performance. Table 5 summarizes the findings of the mediation test using a

\begin{tabular}{|c|c|c|c|c|c|c|c|}
\hline No. & Path & Path coefficient & Supported & $R^{2}$ & $Q^{2}$ & GoF & \\
\hline H1 & BDA capabilities $\rightarrow$ SC performance & $0.07 * *$ & NO & & & & \\
\hline H3 & $\mathrm{SC}$ resilience $\rightarrow \mathrm{SC}$ performance & $0.56^{* * * *}$ & YES & 0.51 & 0.37 & 0.55 & \\
\hline H6 & SC innovation $\rightarrow$ SC performance & $0.47^{* * *}$ & YES & & & & \\
\hline $\mathrm{H} 2$ & BDA capabilities $\rightarrow$ SC resilience & $0.58^{* * *}$ & YES & 0.42 & 0.28 & 0.48 & Table 4. \\
\hline H5 & BDA capabilities $\rightarrow$ SC innovation & $0.49 * * *$ & YES & 0.37 & 0.25 & 0.47 & Summary of the PLS \\
\hline \multicolumn{7}{|c|}{$\operatorname{Note}(\mathbf{s}): * * * p<0.001 ; * * p<0.01$} & results \\
\hline
\end{tabular}

\section{BDA capability and supply chain \\ performance}

73

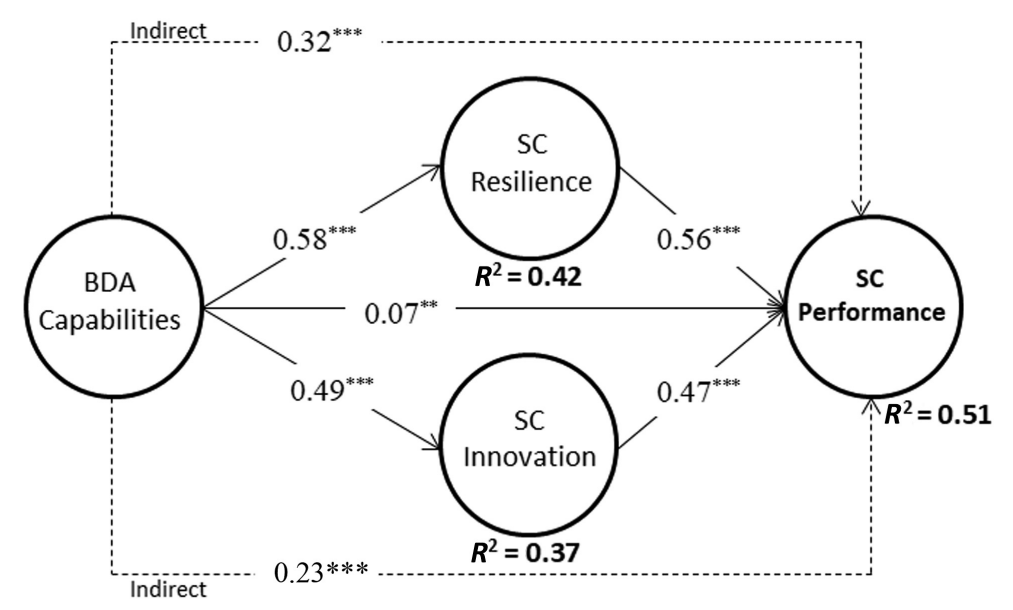

Note(s): **Significant at $P<0.01$

Figure 2.

Structural model

*** Significant at $P<0.001$ 
MSCRA

4,1

\section{4}

bootstrapping approach in SmartPLS3 (Matthews et al., 2018). The indirect effect's significance, as demonstrated in Table 5, qualifies for mediation analysis. Additionally, we estimated variance accounted for (VAF $=$ indirect effect/direct effect + indirect effect) to ascertain the strength of the SC resilience and $\mathrm{SC}$ innovation mediating effects. As mentioned by Hair et al. (2013), partial mediation is shown when (VAF) surpasses the 0.2 threshold level, and when it exceeds 0.8 , full mediation is offered. The findings indicate that $\mathrm{SC}$ resilience entirely mediates the association between BDA capabilities and SC performance, while SC innovations partially mediate the relationship. This prompted us to accept hypotheses $\mathrm{H} 4$ and $\mathrm{H} 7$.

\section{Discussion}

The purpose of this study was to determine how BDA capabilities could impact SC performance via $\mathrm{SC}$ resilience and innovation. To achieve this goal, the concept of BDA capabilities was introduced as a vital capacity that companies should cultivate to reach optimal performance results in the big data age. Statistical results also showed that almost all dimensions (viz. management, infrastructure and personnel expertise capabilities) were equally important in building BDA capabilities. Although no direct association was established between BDA capabilities and SC performance, the empirical findings indicated that BDA capabilities could contribute to SC performance improvement by boosting SC resilience and innovation. In addition, $\mathrm{SC}$ resilience as a full mediator and $\mathrm{SC}$ innovation as a significant partial mediator seemed to strengthen the association between BDA capabilities and $\mathrm{SC}$ performance. The results associated with the effects of BDA capabilities, SC resilience and $\mathrm{SC}$ innovation correspondingly showed an agreement with previous literature and provided new insights into the contribution of all the dimensions to SC performance enhancement.

\subsection{Implications for research}

This study tried to answer how BDAC increases supply chain performance by acknowledging BDAC's favorable impact on several aspects of corporate and supply chain performance in previous research. In addition to boosting supply chain resilience and innovation, $\mathrm{BDAC}$ as a dynamic capability based on $\mathrm{DCV}$, has been found to assist improve overall performance. This is one of the first studies to examine the role of SC resilience and innovation in mediating the relationship between BDA capabilities and $\mathrm{SC}$ performance. By providing insights and strategic orientations, the results contribute to the literature on improving supply chain performance.

\subsection{Implications for practice}

We can safely say that BDAC is improving supply chain performance (Wamba et al., 2020), but its operation is opaque, and it may impact supply chain performance in multiple ways.

Table 5.

\begin{tabular}{llllll}
\hline No. & Mediated path & Support & $\begin{array}{l}\text { Indirect } \\
\text { effect }\end{array}$ & VAF & Conclusion \\
\hline H4 & $\begin{array}{l}\text { BDA capabilities } \rightarrow \text { SC resilience } \rightarrow \text { SC } \\
\text { performance }\end{array}$ & YES & $0.32 * * *$ & 0.82 & Full mediation \\
H7 & $\begin{array}{l}\text { BDA capabilities } \rightarrow \text { SC innovation } \rightarrow \text { SC } \\
\text { performance }\end{array}$ & YES & $0.23 * * *$ & 0.76 & $\begin{array}{l}\text { Partial } \\
\text { mediation }\end{array}$ \\
Note(s): $* * * p<0.001$ & & & & \\
\hline
\end{tabular}


This study's findings demonstrated that BDA capabilities indirectly improve supply chain performance. Accordingly, this study looked at big data from a managerial viewpoint, concentrating on organizational capabilities, rather than a technical or engineering one. The findings indicated that $\mathrm{SC}$ resilience and innovation could act as a mediator between BDA capabilities and SC performance, which could serve as a valuable framework for corporate investment allocation. These findings also corroborated the widespread belief that IT may enable businesses to produce value through intermediary organizational capabilities (Benitez et al., 2018). Like the findings of this study, Wamba et al. (2017) argue that BDA capabilities can provide a competitive advantage in uncertain circumstances. The use of big data analytics to sustain and increase performance through enhancing supply chain resilience and innovation might be the key to success in unexpected environments and supply chain disruption circumstances.

Organizations aimed to increase supply chain visibility can accordingly invest in the adoption and development of BDA capabilities. Given that, the understanding of environmental changes as well as those in supply and demand has augmented in organizations, which has ultimately led to positive performance effects (Srinivasan and Swink, 2018; Dubey et al., 2019). BDA also allows companies to use not only data from downstream and upstream elements of their supply chain but also information from social media and distributed sensors to understand changes in the environment and markets.

The study results accordingly confirmed the positive relationship between BDA capabilities and SC resilience, and that between SC resilience and SC performance, which was in consonance with prior research arguing that $\mathrm{SC}$ resilience could play a key role in the success and effectiveness of BDA projects (Dubey et al., 2021; Singh, N.P. and Singh, S., 2019; Mandal, 2019). These results emphasize the vital role of SC resilience against supply chain disruptions in maintaining its high performance (Christopher and Peck, 2004). Given the functional effects of $\mathrm{SC}$ resilience, managers have to figure out its critical role, as a prerequisite for success in unpredictable environments (Gölgeci and Kuivalainen, 2020). Investing in vertical information systems can increase information-processing capacity (Gupta and George, 2016). In this regard, investing in BDA capabilities can be an effective method that improves SC performance in organizations by escalating coordination between the supply chain members. Organizations that make good use of the quality of information obtained from BDA-based systems can also provide alternative procedures, options and pathways for managing unavoidable supply chain disruptions. These conditions can help organizations continue to provide services, the result of which is customer satisfaction and continued profitability. According to Singh, N.P. and Singh, S. (2019), the study findings also showed that today's organizations cannot only utilize organizational memory to manage the risk of supply chain disruptions, and it is necessary to enter the world of BDA to achieve this goal.

Similarly, BDA capabilities improve SC performance through SC innovation, which was in coherence with prior studies reflecting on the key role of SC innovation in the success and effectiveness of BDA projects (Tan et al., 2015; Fernando et al., 2018; Mikalef et al., 2019; Lozada et al., 2019). The study results also provided empirical evidence for managers with regard to the importance of SC innovation in supporting business value. Managers should thus consider big data as a potential for new knowledge and data analysis as a practical way to attain this new knowledge, which helps managers become aware of decision-making processes and has good potential for innovation in new products and services, marketing methods and new business models. Innovation in products or services also allows companies to quickly adapt to changing market conditions and keep pace with competitors (Corte-Real et al., 2017).

BDA system reports provide managers with insights that enable them to better comprehend market and industry changes, make more informed and timely decisions during 
MSCRA

4,1

76

times of disruption, and respond more effectively. Additionally, the study's findings support the notion that when managers employ innovative technologies to enhance supply chain capabilities, their businesses are likely to acquire a competitive advantage (Akter et al., 2016; Srinivasan and Swink, 2018; Dubey et al., 2019). Notably, retaining a competitive advantage requires continued client service, which leads in enhanced customer happiness and revenue.

BDA capabilities require significant resource and effort inputs. Given that many organizations are only now implementing BDA, it is vital to broaden relevant knowledge and expertise prior to making a successful investment in this area. Furthermore, the findings of the study can be incorporated into a strategic roadmap for managers who are still uncertain or cautious about investing in BDA capabilities. They can effectively manage information assets within firms by implementing this strategic approach (Grover et al., 2018).

In today's data-driven world and markets, investing in big data technology to increase resilience and innovation may be a prudent choice. In this regard, Rogers (2016) reaffirmed that "digital transformation is fundamentally about strategy, not technology." Therefore, managers must regard BDA capabilities as a source of strategic advantage. The current study emphasized managers' critical role in developing various strategies and methods for delivering the expected benefits of BDA capabilities in businesses. Barratt and Oke (2007) argued that competitive advantage was determined by how technology was employed, rather than by the technology itself. So even when BDA capabilities are present, the required economic value may not be realized directly in companies. Finally, while implementing and developing BDA capabilities is a necessary condition for business success, it is insufficient. Managers must first consider all of BDA's dimensions, including management, infrastructure and personnel expertise capabilities (Wamba et al., 2017; Akter et al., 2016), and then manage and steer these capabilities effectively (Mikalef et al., 2020; Côrte-Real et al., 2017; Günther et al., 2017).

\subsection{Limitations and future directions}

Like prior research, this study had several limitations, probably affecting the results. First, this study was conducted in Iran and the generalizability of the results to other countries in the world needed to be done slightly with care due to the specific conditions of this country. Therefore, future studies are suggested to examine the model through the data collected from different nations. Second, given the study's cross-sectional character, future researchers are encouraged to focus on longitudinal datasets (i.e. investigating the same subject matter over time) in order to assess the study's findings' credibility. Additionally, the fact that data were acquired by a single respondent from each organization raises the possibility of CMB. To lessen this risk, more research is needed to involve more participants as well as more than one respondent from each organization. Thirdly, future research should consider additional sociocultural antecedents, such as management style and environmental uncertainty, as well as moderating variables such as information quality. Finally, the DCV perspectives were merely employed in this study. Other theories, on the other hand, may be used in future research to support the model and its outcomes.

\section{Conclusion}

In this study, the impact of BDA capabilities on SC performance was examined. Despite increased interest in understanding the phenomenon of big data and emphasizing the positive effect of BDA-derived insights on performance, there is still no proper understanding of how BDA capabilities contribute to improving SC performance. Therefore, this study attempted to answer the question as to how and in what ways BDA capabilities develop SC performance. To address this question, a conceptual model was proposed based on the DCV and the evidence in the relevant literature to explore the impact of BDA capabilities on SC 
performance by examining SC resilience and SC innovation. Overall, the findings demonstrated that BDA capabilities had a significant positive effect on SC resilience, SC innovation and SC performance, with SC resilience and SC innovation identified as the significant mediators. The main findings of this study are presented in detail as follows:

First, BDA capability can be a strategic investment in improving SC performance.

Second, companies should invest in SC resilience and SC innovation development supported by BDA capabilities, since they are strong mediators between BDA capabilities and SC performance.

\section{References}

Acar, A.Z. and Uzunlar, M.B. (2014), "The effects of process development and information technology on time-based supply chain performance", Procedia-Social and Behavioral Sciences, Vol. 150, pp. 744-753.

Akter, S., Wamba, S.F., Gunasekaran, A., Dubey, R. and Childe, S.J. (2016), "How to improve firm performance using big data analytics capability and business strategy alignment?", International Journal of Production Economics, Vol. 182, pp. 113-131.

Al-Sa'di, A.F., Abdallah, A.B. and Dahiyat, S.E. (2017), "The mediating role of product and process innovations on the relationship between knowledge management and operational performance in manufacturing companies in Jordan”, Business Process Management Journal, Vol. 23 No. 2, pp. 349-376.

Alolah, T., Stewart, R.A., Panuwatwanich, K. and Mohamed, S. (2014), "Determining the causal relationships among balanced scorecard perspectives on school safety performance: case of Saudi Arabia”, Accident Analysis \& Prevention, Vol. 68, pp. 57-74.

Altay, N., Gunasekaran, A., Dubey, R. and Childe, S.J. (2018), "Agility and resilience as antecedents of supply chain performance under moderating effects of organizational culture within the humanitarian setting: a dynamic capability view", Production Planning \& Control, Vol. 29 No. 14, pp. 1158-1174.

Ambulkar, S., Blackhurst, J. and Grawe, S. (2015), "Firm's resilience to supply chain disruptions: scale development and empirical examination", Journal of Operations Management, Vol. 33, pp. 111-122.

Armstrong, J.S. and Overton, T.S. (1977), "Estimating nonresponse bias in mail surveys", Journal of Marketing Research, Vol. 14 No. 3, pp. 396-402.

Ashrafi, A., Ravasan, A.Z., Trkman, P. and Afshari, S. (2019), "The role of business analytics capabilities in bolstering firms' agility and performance", International Journal of Information Management, Vol. 47, pp. 1-15.

Bahrami, M. and Shokouhyar, S. (2021), "The role of big data analytics capabilities in bolstering supply chain resilience and firm performance: a dynamic capability view", Information Technology \& People, Vol. ahead-of-print No. ahead-of-print. doi: 10.1108/ITP-01-2021-0048.

Barratt, M. and Oke, A. (2007), "Antecedents of supply chain visibility in retail supply chains: a resource-based theory perspective”, Journal of Operations Management, Vol. 25 No. 6, pp. 1217-1233.

Beamon, B.M. (1999), "Measuring supply chain performance”, International Journal of Operations \& Production Management, Vol. 19 No. 3, pp. 275-292.

Bello, D.C., Lohtia, R. and Sangtani, V. (2004), "An institutional analysis of supply chain innovations in global marketing channels", Industrial Marketing Management, Vol. 33 No. 1, pp. 57-64.

Benitez, J., Castillo, A., Llorens, J. and Braojos, J. (2018), "IT-enabled knowledge ambidexterity and innovation performance in small US firms: the moderator role of social media capability", Information \& Management, Vol. 55 No. 1, pp. 131-143. 
MSCRA

4,1
Bose, R. (2009), "Advanced analytics: opportunities and challenges", Industrial Management \& Data Systems, Vol. 109 No. 2, pp. 155-172.

Brandon-Jones, E., Squire, B., Autry, C.W. and Petersen, K.J. (2014), "A contingent resource-based perspective of supply chain resilience and robustness", Journal of Supply Chain Management, Vol. 50 No. 3, pp. 55-73.

Chae, B.K. (2014), "A complexity theory approach to IT-enabled services (IESs) and service innovation: business analytics as an illustration of IES", Decision Support Systems, Vol. 57, pp. 1-10.

Chang, H.H., Wong, K.H. and Chiu, W.S. (2019), "The effects of business systems leveraging on supply chain performance: process innovation and uncertainty as moderators", Information \& Management, Vol. 56 No. 6, pp. 103-140.

Chapman, R.L., Soosay, C. and Kandampully, J. (2002), "Innovation in logistic services and the new business model: a conceptual framework", Managing Service Quality: An International Journal, Vol. 12 No. 6, pp. 358-371.

Choi, T.M., Wallace, S.W. and Wang, Y. (2018), "Big data analytics in operations management", Production and Operations Management, Vol. 27 No. 10, pp. 1868-1883.

Chowdhury, M.M.H. and Quaddus, M. (2017), "Supply chain resilience: conceptualization and scale development using dynamic capability theory", International Journal of Production Economics, Vol. 188, pp. 185-204.

Christopher, M. (2005), Logistics and Supply Chain Management: Creating Value-Adding Networks, Prentice-Hall, Harlow.

Christopher, M. and Peck, H. (2004), "Building the resilient supply chain", The International Journal of Logistics Management, Vol. 15 No. 2, pp. 1-14.

Chung, W. and Tseng, T.-L.B. (2012), "Discovering business intelligence from online product reviews: a rule-induction framework", Expert Systems with Applications, Vol. 39 No. 15, pp. 11870-11879.

Côrte-Real, N., Oliveira, T. and Ruivo, P. (2017), "Assessing business value of big data analytics in European firms”, Journal of Business Research, Vol. 70, pp. 379-390.

Côrte-Real, N., Ruivo, P. and Oliveira, T. (2020), "Leveraging internet of things and big data analytics initiatives in European and American firms: is data quality a way to extract business value?”, Information \& Management, Vol. 57 No. 1, pp. 103-141.

Cohen, J. (1988), Statistical Power Analysis for the Behavioral Sciences, 2nd ed., Erlbaum, Hillsdale, NJ.

Craighead, C.W., Blackhurst, J., Rungtusanatham, M.J. and Handfield, R.B. (2007), "The severity of supply chain disruptions: design characteristics and mitigation capabilities", Decision Sciences, Vol. 38 No. 1, pp. 131-156.

DeGroote, S.E. and Marx, T.G. (2013), "The impact of IT on supply chain agility and firm performance: an empirical investigation", International Journal of Information Management, Vol. 33 No. 6, pp. 909-916.

Dijkstra, T.K. and Henseler, J. (2015), “Consistent and asymptotically normal PLS estimators for linear structural equations", Computational Statistics \& Data Analysis, Vol. 81, pp. 10-23.

Dubey, R., Gunasekaran, A. and Childe, S.J. (2019), "Big data analytics capability in supply chain agility”, Management Decision, Vol. 57 No. 8, pp. 2092-2112.

Dubey, R., Gunasekaran, A., Childe, S.J., Fosso Wamba, S., Roubaud, D. and Foropon, C. (2021), "Empirical investigation of data analytics capability and organizational flexibility as complements to supply chain resilience", International Journal of Production Research, Vol. 59 No. 1, pp. 110-128.

Dwayne Whitten, G., Green, K.W. and Zelbst, P.J. (2012), "Triple-A supply chain performance", International Journal of Operations \& Production Management, Vol. 32 No. 1, pp. 28-48.

Eisenhardt, K.M. and Martin, J.A. (2000), "Dynamic capabilities: what are they?", Strategic Management Journal, Vol. 21 Nos 10-11, pp. 1105-1121. 
Farrell, A.M. (2010), "Insufficient discriminant validity: a comment on Bove, Pervan, Beatty, and Shiu (2009)", Journal of Business Research, Vol. 63, pp. 324-327.

Fernando, Y., Chidambaram, R.R. and Wahyuni-TD, I.S. (2018), "The impact of Big Data analytics and data security practices on service supply chain performance", Benchmarking: An International Journal, Vol. 25 No. 9, pp. 4009-4034.

Flint, D.J., Larsson, E. and Gammelgaard, B. (2008), "Exploring processes for customer value insights, supply chain learning and innovation: an international study", Journal of Business Logistics, Vol. 29 No. 1, pp. 257-281.

Flynn, B.B., Sakakibara, S., Schroeder, R.G., Bates, K.A. and Flynn, E.J. (1990), "Empirical research methods in operations management", Journal of Operations Management, Vol. 9 No. 2, pp. 250-284.

Fornell, C. and Larcker, D.F. (1981), "Evaluating structural equation models with unobservable variables and measurement error", Journal of Marketing Research, Vol. 18 No. 1, pp. 39-50.

Gable, G.G. (1994), "Integrating case study and survey research methods: an example in information systems", European Journal of Information Systems, Vol. 3 No. 2, pp. 112-126.

Gölgeci, I. and Kuivalainen, O. (2020), "Does social capital matter for supply chain resilience? The role of absorptive capacity and marketing-supply chain management alignment", Industrial Marketing Management, Vol. 84, pp. 63-74.

Gobble, M.M. (2013), "Big data: the next big thing in innovation”, Research-Technology Management, Vol. 56 No. 1, pp. 64-67.

Govindan, K., Azevedo, S.G., Carvalho, H. and Cruz-Machado, V. (2015), "Lean, green and resilient practices influence on supply chain performance: interpretive structural modeling approach”, International Journal of Environmental Science and Technology, Vol. 12 No. 1, pp. 15-34.

Grover, V., Chiang, R.H., Liang, T.P. and Zhang, D. (2018), "Creating strategic business value from big data analytics: a research framework", Journal of Management Information Systems, Vol. 35 No. 2, pp. 388-423.

Günther, W.A., Mehrizi, M.H.R., Huysman, M. and Feldberg, F. (2017), "Debating big data: a literature review on realizing value from big data", The Journal of Strategic Information Systems, Vol. 26 No. 3, pp. 191-209.

Gunasekaran, A., Papadopoulos, T., Dubey, R., Wamba, S.F., Childe, S.J., Hazen, B. and Akter, S. (2017), "Big data and predictive analytics for supply chain and organizational performance", Journal of Business Research, Vol. 70, pp. 308-317.

Gupta, M. and George, J.F. (2016), "Toward the development of a big data analytics capability", Information \& Management, Vol. 53 No. 8, pp. 1049-1064.

Hair, J.F., Ringle, C.M. and Sarstedt, M. (2011), "PLS-SEM: indeed a silver bullet", Journal of Marketing Theory and Practice, Vol. 19 No. 2, pp. 139-152.

Hair, J.F., Ringle, C.M. and Sarstedt, M. (2013), "Partial least squares structural equation modeling: rigorous applications, better results and higher acceptance", Long Range Planning, Vol. 46 Nos 1-2, pp. 1-12.

Hair, J.F., Jr, Sarstedt, M., Hopkins, L. and Kuppelwieser, V.G. (2014), "Partial least squares structural equation modeling (PLS-SEM)”, European Business Review, Vol. 26 No. 2, pp. 106-121.

Hair, J.F., Jr., Hult, G.T.M., Ringle, C. and Sarstedt, M. (2016), A Primer on Partial Least Squares Structural Equation Modeling (PLS-SEM), Sage Publications, Thousand Oaks, CA.

Hair, J.F., Risher, J.J., Sarstedt, M. and Ringle, C.M. (2019), "When to use and how to report the results of PLS-SEM", European Business Review, Vol. 31 No. 1, pp. 2-24.

Hazen, B.T., Overstreet, R.E. and Cegielski, C.G. (2012), "Supply chain innovation diffusion: going beyond adoption", The International Journal of Logistics Management, Vol. 23 No. 1, pp. 119-134.
BDA capability and supply chain

performance 
MSCRA

4,1
Henseler, J., Ringle, C. and Sarstedt, M. (2012), "Using partial least squares path modeling in international advertising research: basic concepts and recent issues", in Okazaki, J. (Ed.), Handbook of Research on International Advertising, Edward Elgar Publishing, Cheltenham, pp. 252-276.

Henseler, J., Ringle, C.M. and Sarstedt, M. (2015), "A new criterion for assessing discriminant validity in variance-based structural equation modeling", Journal of the Academy of Marketing Science, Vol. 43 No. 1, pp. 115-135.

Henseler, J., Hubona, G. and Ray, P.A. (2016), "Using PLS path modeling in new technology research: updated guidelines", Industrial Management \& Data Systems, Vol. 116 No. 1, pp. 2-20.

Hohenstein, N.O., Feisel, E., Hartmann, E. and Giunipero, L. (2015), "Research on the phenomenon of supply chain resilience", International Journal of Physical Distribution \& Logistics Management, Vol. 45 Nos 1/2, pp. 90-117.

Holling, C.S. (1973), "Resilience and stability of ecological systems", Annual Review of Ecology and Systematics, Vol. 4 No. 1, pp. 1-23.

Isaksson, R., Johansson, P. and Fischer, K. (2010), "Detecting supply chain innovation potential for sustainable development", Journal of Business Ethics, Vol. 97 No. 3, pp. 425-442.

Ivanov, D., Dolgui, A. and Sokolov, B. (2019), "The impact of digital technology and Industry 4.0 on the ripple effect and supply chain risk analytics", International Journal of Production Research, Vol. 57 No. 3, pp. 829-846.

Jha, A.K., Agi, M.A. and Ngai, E.W. (2020), "A note on big data analytics capability development in supply chain”, Decision Support Systems, Vol. 138, 113382.

Jüttner, U. and Maklan, S. (2011), "Supply chain resilience in the global financial crisis: an empirical study”, Supply Chain Management: An International Journal, Vol. 16 No. 4, pp. 246-259.

Kache, F. and Seuring, S. (2017), "Challenges and opportunities of digital information at the intersection of Big Data Analytics and supply chain management”, International Journal of Operations \& Production Management, Vol. 37 No. 1, pp. 10-36.

Kamalahmadi, M. and Parast, M.M. (2016), "A review of the literature on the principles of enterprise and supply chain resilience: major findings and directions for future research", International Journal of Production Economics, Vol. 171, pp. 116-133.

Kock, N. (2015), "Common method bias in PLS-SEM: a full collinearity assessment approach", International Journal of E-Collaboration (Ijec), Vol. 11 No. 4, pp. 1-10.

Kumar, S. and Anbanandam, R. (2020), "Impact of risk management culture on supply chain resilience: an empirical study from Indian manufacturing industry", Proceedings of the Institution of Mechanical Engineers, Part O: Journal of Risk and Reliability, Vol. 234 No. 2, pp. 246-259.

Kwak, D.W., Seo, Y.J. and Mason, R. (2018), "Investigating the relationship between supply chain innovation, risk management capabilities and competitive advantage in global supply chains", International Journal of Operations \& Production Management, Vol. 38 No. 1, pp. 2-21.

Laursen, G.H. and Thorlund, J. (2016), Business Analytics for Managers: Taking Business Intelligence Beyond Reporting, Wiley and SAS Business Series, John Wiley \& Sons, NJ.

Lee, S.M., Lee, D. and Schniederjans, M.J. (2011), "Supply chain innovation and organizational performance in the healthcare industry", International Journal of Operations \& Production Management, Vol. 31 No. 11, pp. 1193-1214.

Lee, V.H., Ooi, K.B., Chong, A.Y.L. and Seow, C. (2014), "Creating technological innovation via green supply chain management: an empirical analysis", Expert Systems with Applications, Vol. 41 No. 16, pp. 6983-6994.

Li, L., Chi, T., Hao, T. and Yu, T. (2018), "Customer demand analysis of the electronic commerce supply chain using Big Data”, Annals of Operations Research, Vol. 268 No. 1, pp. 113-128. 
Lii, P. and Kuo, F.I. (2016), "Innovation-oriented supply chain integration for combined competitiveness and firm performance", International Journal of Production Economics, Vol. 174, pp. 142-155.

Lin, C.Y. (2008), "Determinants of the adoption of technological innovations by logistics service providers in China", International Journal of Technology Management \& Sustainable Development, Vol. 7 No. 1, pp. 19-38.

Liu, C.L. and Lee, M.Y. (2018), "Integration, supply chain resilience, and service performance in third party logistics providers", The International Journal of Logistics Management, Vol. 29 No. 1 , pp. 5-21.

Lozada, N., Arias-Pérez, J. and Perdomo-Charry, G. (2019), "Big data analytics capability and coinnovation: an empirical study", Heliyon, Vol. 5 No. 10, p. e02541.

Maheshwari, S., Gautam, P. and Jaggi, C.K. (2020), "Role of Big Data Analytics in supply chain management: current trends and future perspectives", International Journal of Production Research, Vol. 59 No. 6, pp. 1875-1900.

Mandal, S. (2018), "An examination of the importance of big data analytics in supply chain agility development", Management Research Review, Vol. 41 No. 10, pp. 1201-1219.

Mandal, S. (2019), "The influence of big data analytics management capabilities on supply chain preparedness, alertness and agility", Information Technology \& People, Vol. 32 No. 2, pp. 297-318.

Matthews, L., Hair, J.F. and Matthews, R. (2018), "PLS-SEM: the holy grail for advanced analysis”, The Marketing Management Journal, Vol. 28 No. 1, pp. 1-13.

Mikalef, P. and Krogstie, J. (2018), "Big data analytics as an enabler of process innovation capabilities: a configurational approach", 16th International Conference, Business Process Management, Sydney, Springer, pp. 426-441.

Mikalef, P., Pappas, I.O., Krogstie, J. and Giannakos, M. (2018), "Big data analytics capabilities: a systematic literature review and research agenda", Information Systems and e-Business Management, Vol. 16 No. 3, pp. 547-578.

Mikalef, P., Boura, M., Lekakos, G. and Krogstie, J. (2019), "Big data analytics capabilities and innovation: the mediating role of dynamic capabilities and moderating effect of the environment”, British Journal of Management, Vol. 30 No. 2, pp. 272-298.

Mikalef, P., Krogstie, J., Pappas, I.O. and Pavlou, P. (2020), "Exploring the relationship between big data analytics capability and competitive performance: the mediating roles of dynamic and operational capabilities", Information \& Management, Vol. 57 No. 2, pp. 103-169.

Mishra, D., Gunasekaran, A., Papadopoulos, T. and Childe, S.J. (2018), "Big Data and supply chain management: a review and bibliometric analysis", Annals of Operations Research, Vol. 270 No. 1, pp. 313-336.

Panayides, P.M. and Lun, Y.V. (2009), "The impact of trust on innovativeness and supply chain performance", International Journal of Production Economics, Vol. 122 No. 1, pp. 35-46.

Papadopoulos, T., Gunasekaran, A., Dubey, R., Altay, N., Childe, S.J. and Fosso-Wamba, S. (2017), "The role of Big Data in explaining disaster resilience in supply chains for sustainability", Journal of Cleaner Production, Vol. 142, pp. 1108-1118.

Peng, D.X. and Lai, F. (2012), "Using partial least squares in operations management research: a practical guideline and summary of past research", Journal of Operations Management, Vol. 30 No. 6, pp. 467-480.

Pettit, T.J., Croxton, K.L. and Fiksel, J. (2013), "Ensuring supply chain resilience: development and implementation of an assessment tool", Journal of Business Logistics, Vol. 34 No. 1, pp. 124-143.

Podsakoff, P.M. and Organ, D.W. (1986), "Self-reports in organizational research: problems and prospects”, Journal of Management, Vol. 12 No. 4, pp. 531-544. 
MSCRA

4,1

Podsakoff, P.M., MacKenzie, S.B., Lee, J.Y. and Podsakoff, N.P. (2003), "Common method biases in behavioral research: a critical review of the literature and recommended remedies", Journal of Applied Psychology, Vol. 88 No. 8, pp. 879-903.

Ponomarov, S.Y. and Holcomb, M.C. (2009), "Understanding the concept of supply chain resilience", The International Journal of Logistics Management, Vol. 20 No. 1, pp. 135-150.

Preacher, K.J. and Hayes, A.F. (2008), "Asymptotic and resampling strategies for assessing and comparing indirect effects in multiple mediator models", Behavior Research Methods, Vol. 40 No. 3, pp. 879-891.

Queiroz, M.M. and Telles, R. (2018), "Big data analytics in supply chain and logistics: an empirical approach", The International Journal of Logistics Management, Vol. 29 No. 2, pp. 767-783.

Ramezankhani, M.J., Torabi, S.A. and Vahidi, F. (2018), "Supply chain performance measurement and evaluation: a mixed sustainability and resilience approach", Computers \& Industrial Engineering, Vol. 126, pp. 531-548.

Redman, C.L. (2014), "Should sustainability and resilience be combined or remain distinct pursuits?", Ecology and Society, Vol. 19 No. 2, p. 37.

Rialti, R., Marzi, G., Silic, M. and Ciappei, C. (2018), "Ambidextrous organization and agility in big data era”, Business Process Management Journal, Vol. 24 No. 5, pp. 1091-1109.

Rogers, D. (2016), The Digital Transformation Playbook: Rethink Your Business for the Digital Age, Columbia University Press, New York.

Rosenzweig, E.G., Roth, A.V. and Dean, J.W., Jr (2003), "The influence of an integration strategy on competitive capabilities and business performance: an exploratory study of consumer products manufacturers", Journal of Operations Management, Vol. 21 No. 4, pp. 437-456.

Sabahi, S. and Parast, M.M. (2020), "Firm innovation and supply chain resilience: a dynamic capability perspective", International Journal of Logistics Research and Applications, Vol. 23 No. 3, pp. 254-269.

Sangari, M.S. and Razmi, J. (2015), "Business intelligence competence, agile capabilities and agile performance in supply chain", The International Journal of Logistics Management, Vol. 26 No. 2, pp. 356-380.

Seo, Y.J., Dinwoodie, J. and Kwak, D.W. (2014), "The impact of innovativeness on supply chain performance: is supply chain integration a missing link?", Supply Chain Management: An International Journal, Vol. 19 Nos 5/6, pp. 733-746.

Sezen, B. (2008), "Relative effects of design, integration and information sharing on supply chain performance", Supply Chain Management: An International Journal, Vol. 13 No. 3, pp. 233-240.

Singh, N.P. and Singh, S. (2019), "Building supply chain risk resilience: role of big data analytics in supply chain disruption mitigation", Benchmarking: An International Journal, Vol. 26 No. 7, pp. 2318-2342.

Sobel, M.E. (1982), "Asymptotic confidence intervals for indirect effects in structural equations models", in Leinhart, S. (Ed.), Sociological Methodology, Jossey-Bass, San Francisco, CA, pp. 290-312.

Srinivasan, R. and Swink, M. (2018), "An investigation of visibility and flexibility as complements to supply chain analytics: an organizational information processing theory perspective", Production and Operations Management, Vol. 27 No. 10, pp. 1849-1867.

Tan, K.H., Zhan, Y., Ji, G., Ye, F. and Chang, C. (2015), "Harvesting big data to enhance supply chain innovation capabilities: an analytic infrastructure based on deduction graph", International Journal of Production Economics, Vol. 165, pp. 223-233.

Teece, D.J. (2007), "Explicating dynamic capabilities: the nature and micro foundations of (sustainable) enterprise performance", Strategic Management Journal, Vol. 28 No. 13, pp. 1319-1350.

Teece, D.J., Pisano, G. and Shuen, A. (1997), "Dynamic capabilities and strategic management", Strategic Management Journal, Vol. 18 No. 7, pp. 509-533. 
Wadho, W. and Chaudhry, A. (2018), "Innovation and firm performance in developing countries: the case of Pakistani textile and apparel manufacturers", Research Policy, Vol. 47 No. 7, pp. 1283-1294.

Waller, M.A. and Fawcett, S.E. (2013), "Data science, predictive analytics, and big data: a revolution that will transform supply chain design and management", Journal of Business Logistics, Vol. 34 No. 2, pp. 77-84.

Wamba, S.F., Gunasekaran, A., Akter, S., Ren, S.J.F., Dubey, R. and Childe, S.J. (2017), "Big data analytics and firm performance: effects of dynamic capabilities", Journal of Business Research, Vol. 70 No. 1, pp. 356-365.

Wamba, S.F., Dubey, R., Gunasekaran, A. and Akter, S. (2020), "The performance effects of big data analytics and supply chain ambidexterity: the moderating effect of environmental dynamism", International Journal of Production Economics, Vol. 222, 107498.

Wang, X. and Dass, M. (2017), "Building innovation capability: the role of top management innovativeness and relative-exploration orientation", Journal of Business Research, Vol. 76, pp. 127-135.

Wang, G., Gunasekaran, A., Ngai, E.W. and Papadopoulos, T. (2016), "Big data analytics in logistics and supply chain management: certain investigations for research and applications", International Journal of Production Economics, Vol. 176, pp. 98-110.

Wang, Y., Kung, L. and Byrd, T.A. (2018a), "Big data analytics: understanding its capabilities and potential benefits for healthcare organizations", Technological Forecasting and Social Change, Vol. 126, pp. 3-13.

Wang, Y., Kung, L., Wang, W.Y.C. and Cegielski, C.G. (2018b), "An integrated big data analyticsenabled transformation model: application to health care", Information \& Management, Vol. 55 No. 1, pp. 64-79.

Warner, K.S. and Wäger, M. (2019), "Building dynamic capabilities for digital transformation: an ongoing process of strategic renewal”, Long Range Planning, Vol. 53 No. 3, pp. 326-349.

Wieland, A. and Wallenburg, C.M. (2013), "The influence of relational competencies on supply chain resilience: a relational view", International Journal of Physical Distribution \& Logistics Management, Vol. 43 No. 4, pp. 300-320.

Wong, D.T. and Ngai, E.W. (2019), "Critical review of supply chain innovation research (1999-2016)", Industrial Marketing Management, Vol. 82, pp. 158-187.

\section{Corresponding author}

Mohammad Bahrami can be contacted at: mohammad.bahrami@mail.sbu.ac.ir 


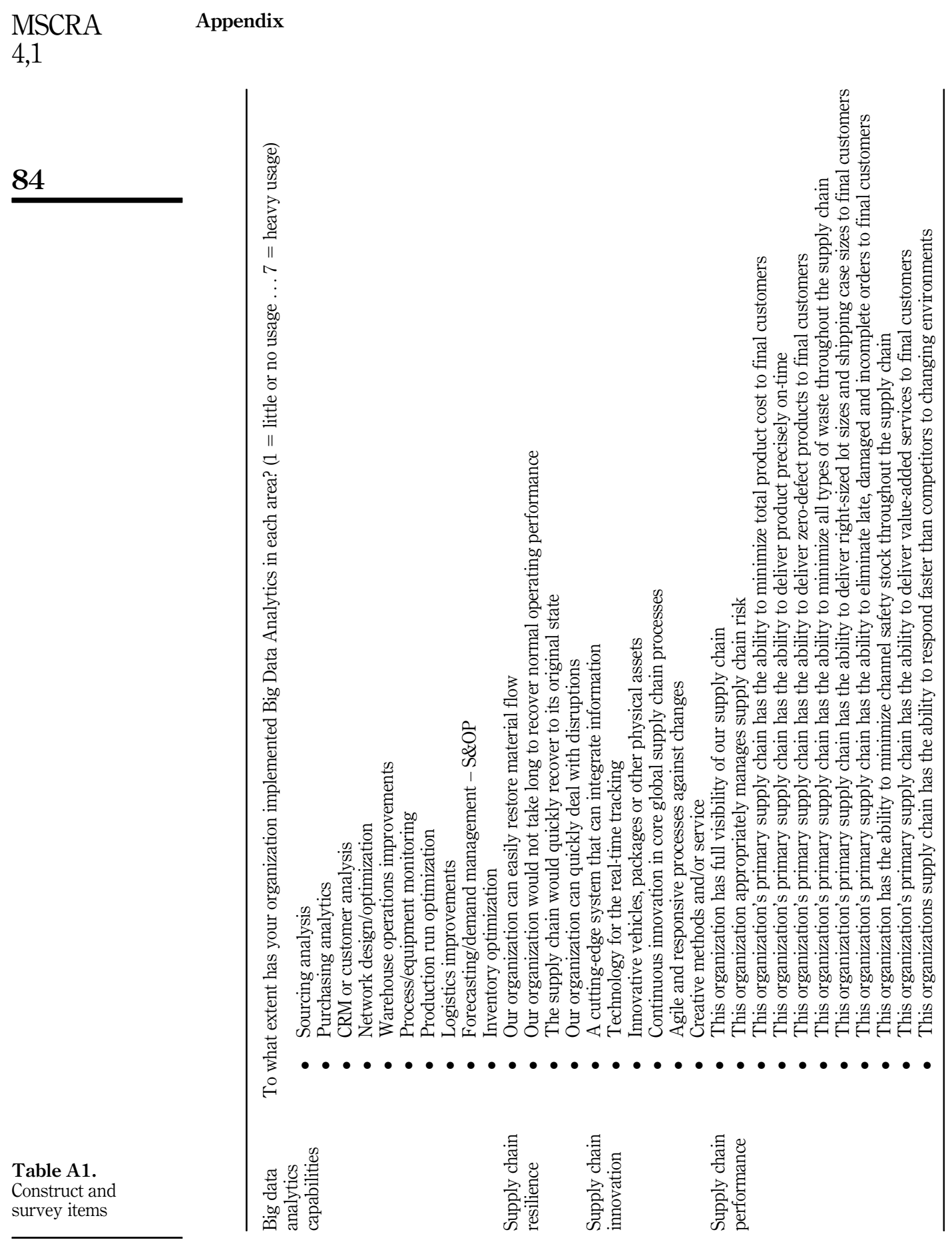

